\title{
New 1,3-diarylureas linked by C-C Suzuki coupling to the methyl 3-aminothieno[3,2-b]pyridine-2-carboxylate moiety: synthesis and fluorescence studies in solution and in lipid membranes
}

\author{
Maria-João R. P. Queiroz, ${ }^{\mathrm{a},{ }^{*}}$ Daniela Peixoto, ${ }^{\mathrm{a}}$ Ana Rita O. Rodrigues, ${ }^{\mathrm{b}}$ Pedro M. F. Mendes, ${ }^{\mathrm{b}}$ \\ Cátia N. C. Costa, ${ }^{b}$ Paulo J. G. Coutinho, ${ }^{b}$ Elisabete M. S. Castanheira, ${ }^{b}$, \\ ${ }^{a}$ Departamento/Centro de Química, Universidade do Minho, Campus de Gualtar, 4710-057 Braga, Portugal \\ ${ }^{b}$ Centro de Física (CFUM), Universidade do Minho, Campus de Gualtar, 4710-057 Braga, Portugal
}

\section{REVISED VERSION}

\begin{abstract}
New six fluorescent 1,3-diarylureas linked by C-C Suzuki coupling to the 6-position of the methyl 3-aminothieno[3,2-b]pyridine-2-carboxylate moiety were prepared by reaction of the amino groups on the ortho or meta positions relative to the $\mathrm{C}-\mathrm{C}$ bond of the Suzuki coupling products, with different para-substituted arylisocyanates $(\mathrm{H}, \mathrm{OMe}, \mathrm{CN})$, in high to excellent yields. The fluorescence properties of the 1,3-diarylureas in solution and in lipid membranes of egg-yolk phosphatidylcholine (Egg-PC), dipalmitoyl phosphatidylcholine (DPPC), dipalmitoyl phosphatidylglycerol (DPPG) or dioctadecyldimethylammonium bromide (DODAB), with or without cholesterol $(\mathrm{Ch})$, were studied. The six 1,3-diarylureas have reasonable fluorescence quantum yields in several solvents $\left(0.02 \leq \Phi_{\mathrm{F}} \leq\right.$ 0.69) and present a moderately solvent sensitive emission, but are not fluorescent in alcohols and water. The compounds bearing the arylurea moiety in the meta position relative to the $\mathrm{C}-\mathrm{C}$ bond, especially with the OMe and $\mathrm{CN}$ substituents, present the better solvatochromic properties.

Incorporation of the six compounds in lipid membranes indicates that all the compounds are deeply located in the hydrophobic region of the lipid bilayers, feeling the transition between the rigid gel phase and fluid phases.
\end{abstract}

Keywords: 1,3-Diarylureas; Thieno[3,2-b]pyridines; Fluorescence; Lipid membranes; Fluorescence probes

\section{Introduction}

Unsymmetrical 1,3-diarylureas have attracted much attention due to their diverse applications in agriculture, medicine, petrochemicals, supramolecular chemistry (anion receptors), biology and as important intermediates and bifunctional organocatalysts in organic synthesis [1-3]. 
Thienopyridines including their 1,3-diarylurea derivatives have shown different biological activities, namely as antitumoral agents [4] and receptor tyrosine kinase inhibitors [5].

In this work, six new 1,3-diarylureas were prepared by reaction of aminated compounds, resulting from Suzuki coupling of methyl 3-amino-6-bromothieno[3,2-b]pyridine-2carboxylate and ortho or meta pinacolborane ester anilines [6], with different para-substituted arylisocyanates $(\mathrm{H}, \mathrm{OMe}, \mathrm{CN})$.

Due to the potential biological activity of the new compounds, their interaction with lipid membranes is of particular interest. The photophysical properties of these thieno[3,2b]pyridine 1,3-diarylurea derivatives in solution and in lipid bilayers were studied. Lipid membranes were composed of neutral/zwitterionic phospholipids (DPPC - dipalmitoyl phosphatidylcholine; Egg-PC - egg yolk phosphatidylcholine), anionic phospholipids (DPPG - dipalmitoyl phosphatidylglycerol) or synthetic cationic lipids (DODAB dioctadecyldimethylammonium bromide). The incorporation of cholesterol, an important component of most natural membranes, may increase the stability of the lipid aggregates by modulating the fluidity of the lipid bilayer, preventing crystallization of the phospholipid acyl chains and providing steric hindrance to their movement [7].

Fluorescence anisotropy measurements can give relevant information about the compounds behavior and location in the lipid membranes, namely if they are located deeply in the lipid bilayer, feeling the differences between the rigid gel phase and the fluid liquid-crystalline phase of the lipids.

\section{Experimental}

\subsection{Synthesis}

\subsubsection{General Remarks}

Melting points $\left({ }^{\circ} \mathrm{C}\right)$ were determined in a SMP3 Stuart apparatus and are uncorrected. ${ }^{1} \mathrm{H}$ and ${ }^{13} \mathrm{C}$ NMR spectra were recorded on a Bruker Avance III at 400 and $100.6 \mathrm{MHz}$ or on a Varian Unity Plus at 300 and $75.4 \mathrm{MHz}$, respectively. Heteronuclear correlations, ${ }^{1} \mathrm{H}-{ }^{13} \mathrm{C}$, HMQC or HSQC were performed to attribute some signals.

HRMS data were recorded using a method of direct injection by ESI-TOF by the mass spectrometry service of the University of Vigo, Spain. 
The reactions were monitored by thin layer chromatography (TLC) in aluminium plates covered with a layer of silica gel 60 (Macherey-Nagel) of $0.2 \mathrm{~mm}$, with $\mathrm{UV}_{254}$ fluorescence indicator.

\subsubsection{General procedure for the synthesis of 1,3-diarylureas (Scheme 1): Compounds 1a-b} [6] and different arylisocyanates (1 equiv.) in $6 \mathrm{~mL} \mathrm{CH}_{2} \mathrm{Cl}_{2}$ : THF (1:1) were left stirring at room temperature for $16 \mathrm{~h}$. If a precipitate didn't come out after this time, hexane $(3-5 \mathrm{~mL})$ was added to the mixture to precipate the product. This was filtered under vacuum to give the corresponding 1,3-diarylureas.

2.1.2.1. Methyl 3-amino-6-[3-(3-phenylureido)phenyl]thieno[3,2-b]pyridine-2-carboxylate (2a): From compound $\mathbf{1 a}(80.0 \mathrm{mg}, 0.270 \mathrm{mmol})$ and phenylisocyanate $(32.0 \mathrm{mg})$ compound 2a was isolated as a yellow solid (100 mg, 90\%), m.p. 226-226.5 ${ }^{\circ} \mathrm{C} .{ }^{1} \mathrm{H}$ NMR (400 MHz, DMSO- $\left.d_{6}\right): \delta 3.83(3 \mathrm{H}, \mathrm{s}, \mathrm{OMe}), 6.93\left(2 \mathrm{H}\right.$, br s, $\left.\mathrm{NH}_{2}\right), 6.95-6.99(1 \mathrm{H}, \mathrm{m}, \mathrm{ArH}), 7.26-7.30$ (2H, m, ArH), 7.40-7.52 (5H, m, ArH), $7.91(1 \mathrm{H}$, broad s, 2'-H), $8.62(1 \mathrm{H}, \mathrm{d}, J=2 \mathrm{~Hz}, 7-\mathrm{H})$, $8.75\left(1 \mathrm{H}\right.$, br s, NH), $8.82\left(1 \mathrm{H}\right.$, br s, NH), $8.93(1 \mathrm{H}, \mathrm{d}, J=2 \mathrm{~Hz}, 5-\mathrm{H}) \mathrm{ppm} .{ }^{13} \mathrm{C}$ NMR (400 MHz, DMSO- $\left.d_{6}\right): \delta 51.5(\mathrm{OMe}), 97.4(\mathrm{C}), 117.0\left(2^{\prime}-\mathrm{CH}\right), 118.3(2 \times \mathrm{CH}) 118.4(\mathrm{CH}), 121.0$ $(\mathrm{CH}), 121.9(\mathrm{CH}), 128.8(2 \times \mathrm{CH}), 129.3(7-\mathrm{CH}), 129.7(\mathrm{CH}), 133.9(\mathrm{C}), 135.1(\mathrm{C}), 137.3(\mathrm{C})$, $139.6(\mathrm{C}), 140.5(\mathrm{C}), 145.4(\mathrm{C}), 145.5(5-\mathrm{CH}), 147.9(\mathrm{C}), 152.6(\mathrm{C}=\mathrm{O}), 164.6(\mathrm{C}=\mathrm{O}) \mathrm{ppm}$. HRMS (ESI-TOF) Calcd. for $\mathrm{C}_{22} \mathrm{H}_{19} \mathrm{~N}_{4} \mathrm{O}_{4} \mathrm{~S}[\mathrm{M}+\mathrm{H}]^{+} 419.1172$; found 419.1188.

2.1.2.2. Methyl 3-amino-6-\{3-[3-(4-methoxyphenyl)ureido]phenyl $\}$ thieno[3,2-b]pyridine-2carboxylate (2b): From compound $1 \mathbf{a}(150 \mathrm{mg}, 0.540 \mathrm{mmol})$ and 4-methoxyphenylisocyanate (80.0 mg) compound $\mathbf{2 b}$ was isolated as a yellow solid $(217 \mathrm{mg}, 90 \%)$, m.p. $243-244{ }^{\circ} \mathrm{C} .{ }^{1} \mathrm{H}$ NMR (400 MHz, DMSO-d $\left.d_{6}\right): \delta 3.71(\mathrm{~s}, 3 \mathrm{H}, \mathrm{OMe}), 3.83(\mathrm{~s}, 3 \mathrm{H}, \mathrm{OMe}), 6.87(2 \mathrm{H}, \mathrm{d}, J=9.2$ $\mathrm{Hz}, 3$ " and 5' '-H), $6.93\left(2 \mathrm{H}, \mathrm{br}, \mathrm{NH}_{2}\right), 7.36(2 \mathrm{H}, \mathrm{d}, J=9.2 \mathrm{~Hz}, 2$ ' ' and 6' $-\mathrm{H}), 7.38-7.50$ (3H, m, ArH), 7.89 (1H, br s, 2'-H), 8.55 (1H, br s, NH), 8.61 (1H, d, J=2.0 Hz, 7-H), 8.73 $\left(1 \mathrm{H}\right.$, broad s, NH), $8.92(1 \mathrm{H}, \mathrm{d}, J=2.0 \mathrm{~Hz}, 5-\mathrm{H}) \mathrm{ppm} .{ }^{13} \mathrm{C}$ NMR $\left(100.6 \mathrm{MHz}\right.$, DMSO- $\left.d_{6}\right): \delta$ 51.6 (OMe), 55.2 (OMe), $97.4(\mathrm{C}), 114.0$ (3'” and 5' '-CH), 116.9 (2'-CH), $118.3(\mathrm{CH}), 120.2$ (2"' and 6" '-CH), $120.8(\mathrm{CH}), 129.3(7-\mathrm{CH}), 129.7(\mathrm{CH}), 132.6(\mathrm{C}), 133.9(\mathrm{C}), 135.2(\mathrm{C})$, 137.3 (C), 140.7 (C), 145.4 (C), 145.5 (5-CH), 147.9 (C), 152.8 (C=O), 154.6 (C), 164.6 $(\mathrm{C}=\mathrm{O})$ ppm. HRMS (ESI-TOF) Calcd. for $\mathrm{C}_{23} \mathrm{H}_{21} \mathrm{~N}_{4} \mathrm{O}_{4} \mathrm{~S}[\mathrm{M}+\mathrm{H}]^{+} 449.1284$; found 449.1284 . 
2.1.2.3. Methyl 3-amino-6-\{3-[3-(4-cyanophenyl)ureido]phenyl $\}$ thieno[3,2- $b$ ]pyridine-2carboxylate (2c): From compound 1a $(100 \mathrm{mg}, 0.330 \mathrm{mmol})$ and 4-cyanophenylisocyanate (50.0 mg) compound $2 \mathrm{c}$ was isolated as a yellow solid $(120 \mathrm{mg}, 80 \%)$, m.p. $264-265{ }^{\circ} \mathrm{C} .{ }^{1} \mathrm{H}$ NMR (300 MHz, DMSO-d $\left.d_{6}\right): \delta 3.83(3 \mathrm{H}, \mathrm{s}, \mathrm{OMe}), 6.94\left(2 \mathrm{H}, \mathrm{br}, \mathrm{NH}_{2}\right), 7.45-7.47(2 \mathrm{H}, \mathrm{m}$, ArH), 7.49-7.54 (1H, m, ArH), $7.65(2 \mathrm{H}, \mathrm{d}, J=9.0 \mathrm{~Hz}, 2$ ', and 6' $-\mathrm{H}), 7.73$ (2H, d, $J=9.0$ Hz, 3' ' and 5' '-H), $7.90(1 \mathrm{H}$, br s, 2'-H), $8.62(1 \mathrm{H}, \mathrm{d}, J=2 \mathrm{~Hz}, 7-\mathrm{H}), 8.92(1 \mathrm{H}, \mathrm{d}, J=2.0 \mathrm{~Hz}$, 5-H), $9.01\left(1 \mathrm{H}\right.$, br s, NH), $9.30\left(1 \mathrm{H}\right.$, br s, NH) ppm. ${ }^{13} \mathrm{C}$ NMR $\left(75.4 \mathrm{MHz}\right.$, DMSO- $\left.d_{6}\right): \delta$ $51.6(\mathrm{OMe}), 97.4(\mathrm{C}), 103.4(\mathrm{C}), 117.4\left(2^{\prime}-\mathrm{CH}\right) 118.1$ (2'” and 6' $\left.-\mathrm{CH}\right), 118.7(\mathrm{CH}) 119.3$ (C), $121.5(\mathrm{CH}), 129.4(7-\mathrm{CH}), 129.8(\mathrm{CH}), 133.3$ (3"' and 5' $-\mathrm{CH}), 133.9(\mathrm{C}), 135.0(\mathrm{C})$, 137.4 (C), 140.0 (C), 144.1 (C), 145.5 (C), 145.6 (5-CH), 147.9 (C), 152.2 (C=O), 164.6 $(\mathrm{C}=\mathrm{O})$ ppm. HRMS (ESI-TOF) Calcd. for $\mathrm{C}_{23} \mathrm{H}_{18} \mathrm{~N}_{5} \mathrm{O}_{3} \mathrm{~S}[\mathrm{M}+\mathrm{H}]^{+} 444.1125$; found 444.1120.

2.1.2.4. Methyl 3-amino-6-[2-(3-phenylureido)phenyl]thieno[3,2-b]pyridine-2-carboxylate (3a): From compound $\mathbf{1 b}(125 \mathrm{mg}, 0.420 \mathrm{mmol})$ and phenylisocyanate $(50.0 \mathrm{mg})$ compound 3a was isolated as a yellow solid (120 mg, 75\%), m.p. 226-227 ${ }^{\circ} \mathrm{C} .{ }^{1} \mathrm{H}$ NMR $(400 \mathrm{MHz}$, DMSO- $\left.d_{6}\right): \delta 3.83(3 \mathrm{H}, \mathrm{s}, \mathrm{OMe}), 6.91-6.95(\mathrm{~m}, 1 \mathrm{H}, \mathrm{ArH}), 6.97\left(2 \mathrm{H}, \mathrm{br}, \mathrm{NH}_{2}\right), 7.17-7.25$ (3H, m, ArH), 7.35-7.44 (4H, m, ArH), $7.86(1 \mathrm{H}$, br s, NH), $8.00(1 \mathrm{H}, \mathrm{dd}, J=8.0$ and 1.2 $\mathrm{Hz}, \mathrm{ArH}), 8.43(1 \mathrm{H}, \mathrm{d}, J=2 \mathrm{~Hz}, 7-\mathrm{H}), 8.65(1 \mathrm{H}, \mathrm{d}, J=2 \mathrm{~Hz}, 5-\mathrm{H}), 8.79$ (1H, br s, NH) ppm. ${ }^{13} \mathrm{C}$ NMR (100.6 MHz, DMSO- $\left.d_{6}\right): \delta 51.6(\mathrm{OMe}), 97.3(\mathrm{C}), 118.0(2 \times \mathrm{CH}), 121.8(\mathrm{CH})$, $122.6(\mathrm{CH}) 123.5(\mathrm{CH}), 128.8(2 \times \mathrm{CH}) 128.9(\mathrm{CH}), 129.1(\mathrm{C}), 130.7(\mathrm{CH}), 132.1(7-\mathrm{CH})$, 133.7 (C), 133.8 (C), 136.5 (C), 139.6 (C), 145.3 (C), 147.3 (5-CH), 148.0 (C), 152.6 (C=O), $164.6(\mathrm{C}=\mathrm{O}) \mathrm{ppm}$. HRMS (ESI-TOF) Calcd. for $\mathrm{C}_{22} \mathrm{H}_{19} \mathrm{~N}_{4} \mathrm{O}_{3} \mathrm{~S}[\mathrm{M}+\mathrm{H}]{ }^{+}$419.1172; found 419.1180 .

2.1.2.5. Methyl 3-amino-6-\{2-[3-(4-methoxyphenyl)ureido]phenyl $\}$ thieno[3,2-b]pyridine-2carboxylate (3b): From compound $\mathbf{1 b} \quad\left(\begin{array}{lllll}100 & \mathrm{mg}, & 0.330 & \mathrm{mmol}\end{array}\right) \quad$ with 4methoxyphenylisocyanate $(50.0 \mathrm{mg})$ compound $\mathbf{3 b}$ was obtained $(100 \mathrm{mg}$, 70\%), m.p. 243$244{ }^{\circ} \mathrm{C} .{ }^{1} \mathrm{H}$ NMR (400 MHz, DMSO-d $\left.d_{6}\right): \delta 3.68$ (3H, s, OMe), 3.83 (3H, s, OMe), $6.81(2 \mathrm{H}$, $\mathrm{d}, J=9.2 \mathrm{~Hz}, 3$ " and 5"- H), $6.97\left(2 \mathrm{H}, \mathrm{br} \mathrm{s}, \mathrm{NH}_{2}\right), 7.15-7.19(1 \mathrm{H}, \mathrm{m}, \mathrm{ArH}), 7.25(2 \mathrm{H}, \mathrm{d}, J=$ $9.2 \mathrm{~Hz}, 2$ " and 6"-H), 7.32-7.35 (1H, m, ArH), 7.38-7.42 (1H, m, ArH), 7.77 (1H, br s, NH), $7.99(1 \mathrm{H}$, br d, $J=8.4 \mathrm{~Hz}, \mathrm{ArH}), 8.42(1 \mathrm{H}, \mathrm{d}, J=2.0 \mathrm{~Hz}, 7-\mathrm{H}), 8.63(1 \mathrm{H}, \mathrm{br} \mathrm{s}, \mathrm{NH}), 8.64(1 \mathrm{H}$, $\mathrm{d}, J=2.0 \mathrm{~Hz}, 5-\mathrm{H}) .{ }^{13} \mathrm{C}\left(100.6 \mathrm{MHz}, \mathrm{DMSO}-d_{6}\right): \delta 51.6(\mathrm{OMe}), 55.1(\mathrm{OMe}), 97.2(\mathrm{C}), 99.7$ (C), 114.0 (3"' and 5' '-CH), 119.8 (2'' and 6"'-CH), $122.3(\mathrm{CH}), 123.2(\mathrm{CH}) 128.9(\mathrm{CH})$, 130.7 (CH), 132.1 (7-CH), 132.6 (C), 133.8 (C), 136.7 (C), 145.3 (C), 147.3 (5-CH), 148.0 
(C), $152.7(\mathrm{C}=\mathrm{O}), 154.4(\mathrm{C}), 164.6(\mathrm{C}=\mathrm{O})$ ppm. HRMS (ESI-TOF) Calcd. for $\mathrm{C}_{23} \mathrm{H}_{21} \mathrm{~N}_{4} \mathrm{O}_{4} \mathrm{~S}$ $[\mathrm{M}+\mathrm{H}]^{+}$449.1284; found 449.1280.

2.1.2.6. Methyl 3-amino-6-\{2-[3-(4-cyanophenyl)ureido]phenyl $\}$ thieno[3,2-b]pyridine-2carboxylate (3c): From compound $\mathbf{1 b}(140 \mathrm{mg}, 0.470 \mathrm{mmol})$ and 4-cyanophenylisocyanate (69.0 mg) compound 3c was isolated as a yellow solid (120 mg, 75\%), m.p. 210-211 ${ }^{\circ} \mathrm{C} .{ }^{1} \mathrm{H}$ NMR (400 MHz, DMSO-d $): \delta 3.83(3 \mathrm{H}, \mathrm{s}, \mathrm{OMe}), 6.96\left(2 \mathrm{H}\right.$, br s, $\left.\mathrm{NH}_{2}\right), 7.22-7.26(1 \mathrm{H}, \mathrm{m}$, ArH), 7.36-7.39 (1H, m, ArH), 7.52-7.55 (1H, m, ArH), $7.53(2 \mathrm{H}, \mathrm{d}, J=8.8 \mathrm{~Hz}, 2$ ' ' and 6"'H), $7.67(2 \mathrm{H}, \mathrm{d}, J=8.8 \mathrm{~Hz}, 3$ ' ' and 5' '-H), 7.93-7.95 (1H, m, ArH), 8.07 (1H, br s, NH), 8.44 $(1 \mathrm{H}, \mathrm{d}, J=2 \mathrm{~Hz}, 7-\mathrm{H}), 8.65(1 \mathrm{H}, \mathrm{d}, J=2.0 \mathrm{~Hz}, 5-\mathrm{H}), 9.28\left(1 \mathrm{H}\right.$, br s, NH) ppm. ${ }^{13} \mathrm{C} \mathrm{NMR}$ (100.6 MHz, DMSO- $\left.d_{6}\right): \delta 51.6(\mathrm{OMe}), 97.3$ (C), 103.3 (C), 117.9 (2" ' and 6" $\left.-\mathrm{CH}\right), 119.3$ (C) $123.2(\mathrm{CH}), 124.2(\mathrm{CH}) 129.0(\mathrm{CH}), 129.8(\mathrm{C}), 130.8(\mathrm{CH}), 132.1(7-\mathrm{CH}), 133.3$ (3', and 5'”-CH), 133.6 (C), 133.7 (C), 135.8 (C), 144.1 (C), 145.3 (C), 147.2 (5-CH), 147.9 (C), $152.3(\mathrm{C}=\mathrm{O}), 164.6(\mathrm{C}=\mathrm{O})$ ppm. HRMS (ESI-TOF) Calcd. for $\mathrm{C}_{23} \mathrm{H}_{18} \mathrm{~N}_{5} \mathrm{O}_{3} \mathrm{~S}[\mathrm{M}+\mathrm{H}]^{+}$ 444.1125; found 444.1129.

\subsection{Lipid membranes preparation}

All the solutions were prepared using spectroscopic grade solvents and ultrapure water (MilliQ grade). 1,2-Dipalmitoyl-sn-glycero-3-phosphocholine (DPPC), 1,2-diacyl-sn-glycero-3phosphocholine from egg yolk (egg-PC), 1,2-dipalmitoyl-sn-glycero-3-[phospho-rac-(1glycerol)] (sodium salt) (DPPG) and cholesterol were obtained from Sigma-Aldrich and dioctadecyldimethylammonium bromide (DODAB) from Tokyo Kasei (lipid structures are shown below).

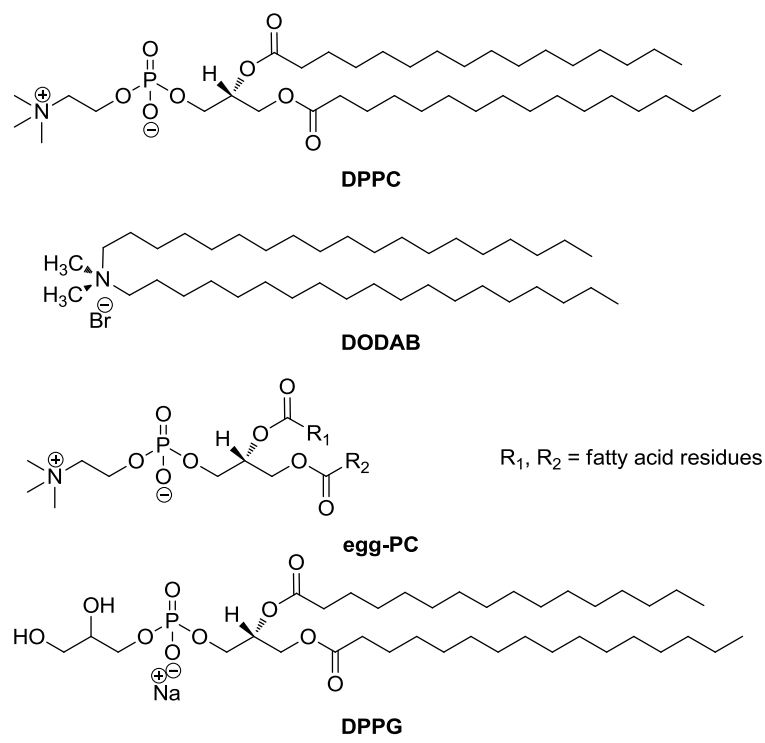


For lipid vesicles preparation, the ethanolic injection method was used [8-10]. For egg-PC membranes preparation, defined volume of stock solution of lipid $(86.2 \mathrm{mM})$ and each compound $(0.3 \mathrm{mM})$ in ethanol were injected together, under vigorous stirring, to an aqueous buffer solution (10 mM Tris, $\mathrm{pH}=7.4)$, at room temperature. A similar procedure was adopted for DPPC, DODAB and DPPG vesicles, but the injection of the required amounts of stock solutions of lipid (50 mM for DPPC, $20 \mathrm{mM}$ for DODAB and $26.8 \mathrm{mM}$ for DPPG) and compounds in ethanol was done at $60^{\circ} \mathrm{C}$, well above the melting transition temperature of each lipid (ca. $41^{\circ} \mathrm{C}$ for DPPC [11], ca. $45^{\circ} \mathrm{C}$ for DODAB [12], and $39.6^{\circ} \mathrm{C}$ for DPPG [13]). In all cases, the final lipid concentration was $1 \mathrm{mM}$, with a compound/lipid molar ratio of $1: 333$.

\subsection{Spectroscopic measurements}

Absorption spectra were recorded in a Shimadzu UV-3101PC UV-Vis-NIR spectrophotometer. Fluorescence measurements were performed using a Fluorolog 3 spectrofluorimeter, equipped with double monochromators in both excitation and emission, Glan-Thompson polarizers and a temperature controlled cuvette holder. Fluorescence spectra were corrected for the instrumental response of the system.

For fluorescence quantum yield determination, the solutions were previously bubbled for 20 minutes with ultrapure nitrogen. The fluorescence quantum yields $\left(\Phi_{\mathrm{s}}\right)$ were determined using the standard method (equation 1) [14,15]. Quinine sulfate in $\mathrm{H}_{2} \mathrm{SO}_{4} 0.05 \mathrm{M}$ was used as reference, $\Phi_{\mathrm{r}}=0.546$ at $25^{\circ} \mathrm{C}[16]$.

$$
\Phi_{\mathrm{s}}=\left\lfloor\left(A_{\mathrm{r}} F_{\mathrm{s}} n_{\mathrm{s}}^{2}\right) /\left(A_{\mathrm{s}} F_{\mathrm{r}} n_{\mathrm{r}}^{2}\right)\right\rfloor \Phi_{\mathrm{r}}
$$

where $A$ is the absorbance at the excitation wavelength, $F$ the integrated emission area and $n$ the refraction index of the solvents used. Subscripts refer to the reference (r) or sample (s) compound. The absorbance value at excitation wavelength was always less than 0.1 , in order to avoid inner filter effects.

Solvatochromic shifts can be described by the Lippert-Mataga equation (2), which relates the energy difference between absorption and emission maxima to the orientation polarizability, $[17,18]$

$$
\bar{v}_{\text {abs }}-\bar{v}_{\mathrm{fl}}=\frac{1}{4 \pi \varepsilon_{0}} \frac{2 \Delta \mu^{2}}{h c R^{3}} \Delta f+\text { const }
$$


where $\bar{v}_{\text {abs }}$ is the wavenumber of maximum absorption, $\bar{v}_{\mathrm{fl}}$ is the wavenumber of maximum emission, $\Delta \mu=\mu_{\mathrm{e}}-\mu_{\mathrm{g}}$ is the difference in the dipole moment of solute molecule between excited $\left(\mu_{\mathrm{e}}\right)$ and ground $\left(\mu_{\mathrm{g}}\right)$ states, $R$ is the cavity radius (considering the fluorophore a point dipole at the center of a spherical cavity immersed in the homogeneous solvent), and $\Delta f$ is the orientation polarizability given by (eq. 3):

$$
\Delta f=\frac{\varepsilon-1}{2 \varepsilon+1}-\frac{n^{2}-1}{2 n^{2}+1},
$$

where $\varepsilon$ is the static dielectric constant and $n$ the refractive index of the solvent.

An alternative expression, proposed by Bakhshiev, takes into account the angle, $\gamma$, between the ground and excited state dipole moments of the fluorophore $[19,20]$ :

$$
\bar{v}_{\mathrm{abs}}-\overline{\mathrm{v}}_{\mathrm{fl}}=\frac{1}{4 \pi \varepsilon_{0}} \frac{2}{h c R^{3}}\left(\mu_{\mathrm{g}}^{2}-2 \mu_{\mathrm{g}} \mu_{\mathrm{e}} \cos \gamma+\mu_{\mathrm{e}}^{2}\right) f(\varepsilon, n)+\text { const }
$$

where $\mu_{\mathrm{g}}^{2}-2 \mu_{\mathrm{g}} \mu_{\mathrm{e}} \cos \gamma+\mu_{\mathrm{e}}^{2}$ is equivalent to $\left|\vec{\mu}_{\mathrm{e}}-\vec{\mu}_{\mathrm{g}}\right|^{2}$ and

$$
f(\varepsilon, n)=\frac{\varepsilon-1}{\varepsilon+2}-\frac{n^{2}-1}{n^{2}+2}
$$

The steady-state fluorescence anisotropy, $r$, is calculated by

$$
r=\frac{I_{\mathrm{VV}}-G I_{\mathrm{VH}}}{I_{\mathrm{VV}}+2 G I_{\mathrm{VH}}}
$$

where $I_{\mathrm{VV}}$ and $I_{\mathrm{VH}}$ are the intensities of the emission spectra obtained with vertical and horizontal polarization, respectively (for vertically polarized excitation light), and $G=I_{\mathrm{HV}} / I_{\mathrm{HH}}$ is the instrument correction factor, where $I_{\mathrm{HV}}$ and $I_{\mathrm{HH}}$ are the emission intensities obtained with vertical and horizontal polarization (for horizontally polarized excitation light).

\section{Results and discussion}

\subsection{Synthesis}

New 1,3-diarylureas 2a-c and 3a-c were prepared by reaction of the aromatic amino groups of the Suzuki coupling products 1a-b, earlier obtained by us from methyl 3-amino-6- 
bromothieno[3,2-b]pyridine-2-carboxylate and pinacolborane esters of anilines [6], with arylisocyanates, in high to excellent yields (Scheme 1).

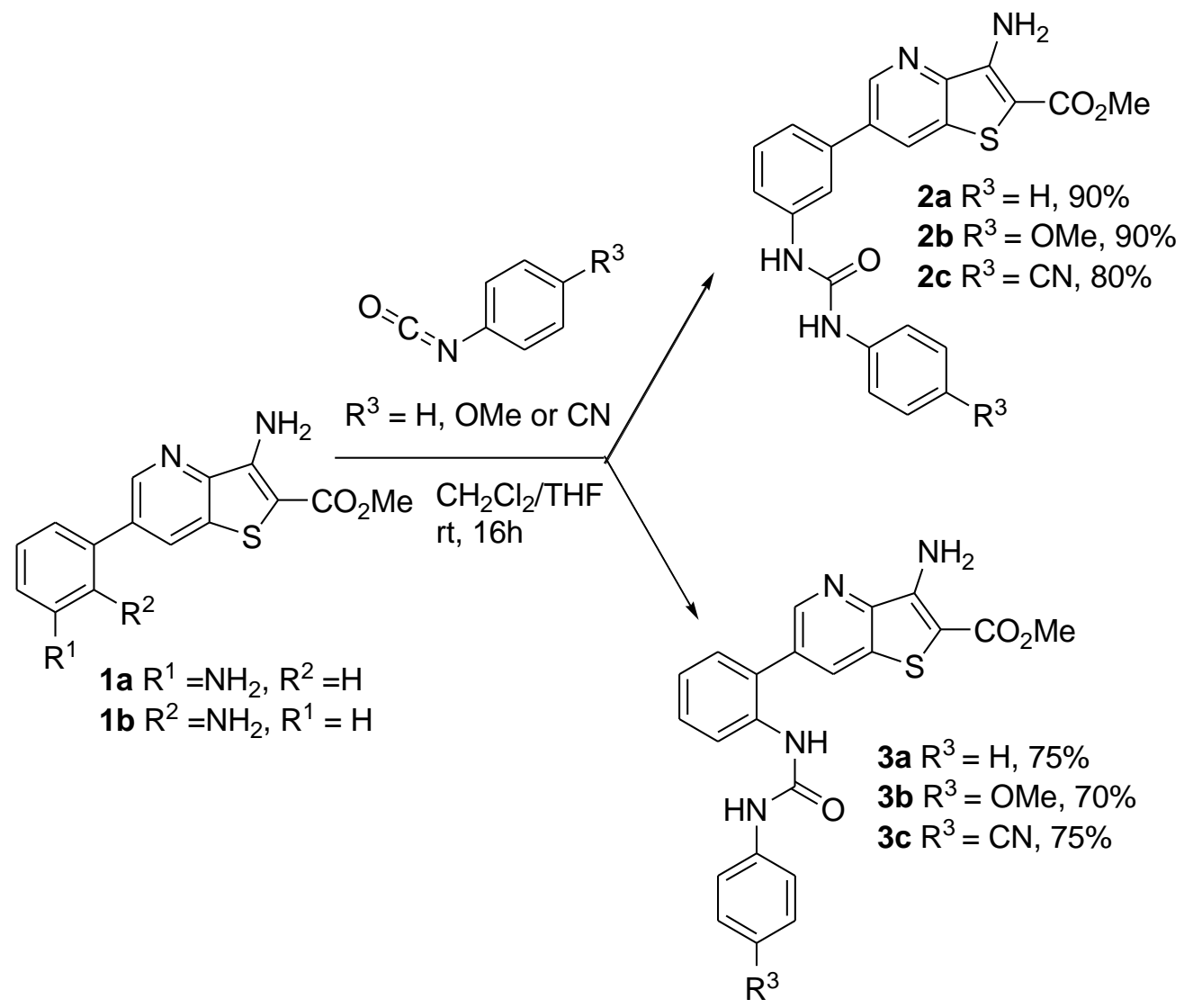

Scheme 1. Synthesis of 1,3-diarylureas $\mathbf{2 - 3}$ derivatives of thieno[3,2-b]pyridines by reaction of anilines with arylisocyanates.

\subsection{Fluorescence studies in several solvents}

The absorption and fluorescence properties of compounds $\mathbf{2 a - c}$ and $\mathbf{3 a - c}$ were studied in several solvents (Table SD1 in Supplementary Data). The normalized fluorescence spectra of compounds 2a, 2c and $\mathbf{3 b}$ are shown in Figures 1, 2 and 3, respectively (examples of absorption spectra are also shown as insets).

Compounds 2a-c and 3a-c exhibit reasonable fluorescence emission in several solvents (the studied solvents do not include cyclo- or $n$-alkanes, because the solubility of these compounds is very poor in this kind of solvents). Fluorescence quantum yield values are in the range of $6 \%$ in chloroform and 65\% in DMSO for compounds $\mathbf{2 a - c}$ and of 2\% (chloroform) and 69\% (DMSO) for compounds 3a-c (Table SD1). However, no emission is observed in protic solvents like water, methanol or ethanol. 


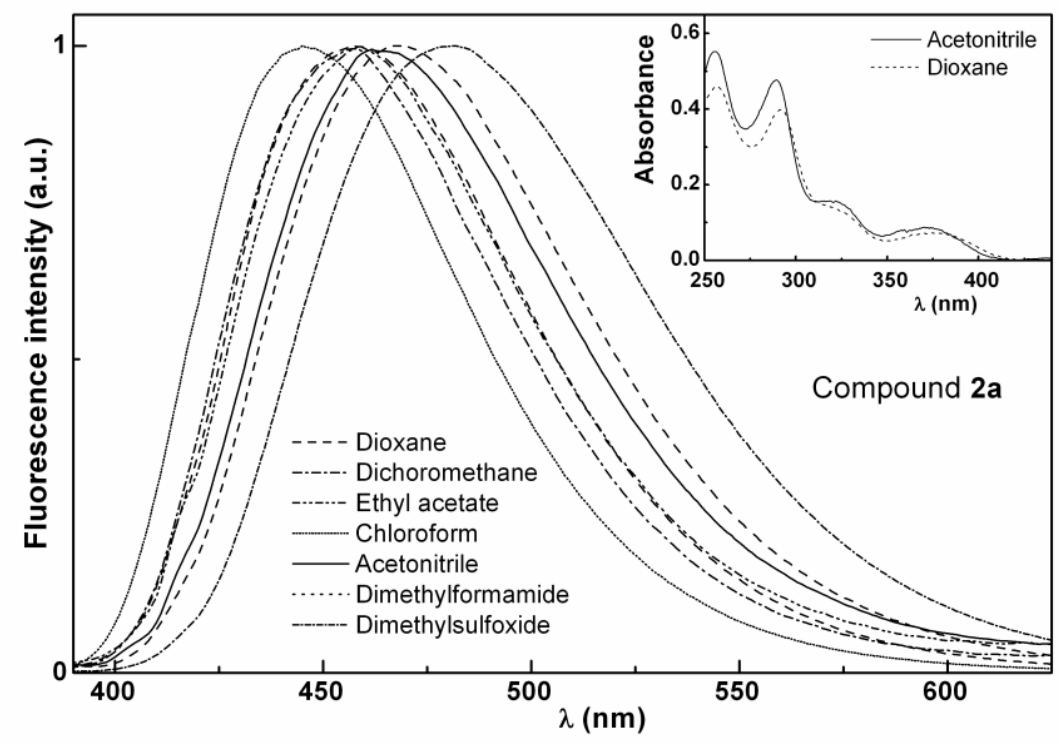

Figure 1. Normalized fluorescence spectra of $3 \times 10^{-6} \mathrm{M}$ solutions of compound 2a in several solvents $\left(\lambda_{\text {exc }}=370 \mathrm{~nm}\right)$. Inset: Absorption spectrum of $10^{-5} \mathrm{M}$ solutions of $2 \mathbf{a}$ in dioxane and acetonitrile, as examples.

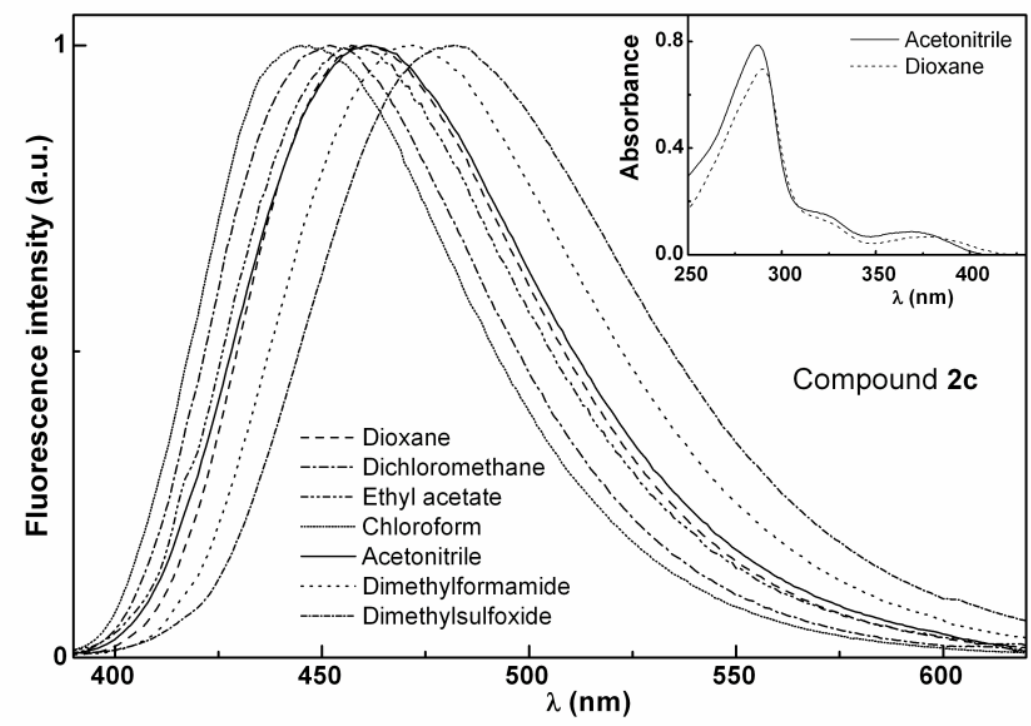

Figure 2. Normalized fluorescence spectra of $3 \times 10^{-6} \mathrm{M}$ solutions of compound $\mathbf{2 c}$ in several solvents $\left(\lambda_{\text {exc }}=370 \mathrm{~nm}\right)$. Inset: Absorption spectrum of $10^{-5} \mathrm{M}$ solutions of $\mathbf{2 c}$ in dioxane and acetonitrile, as examples. 


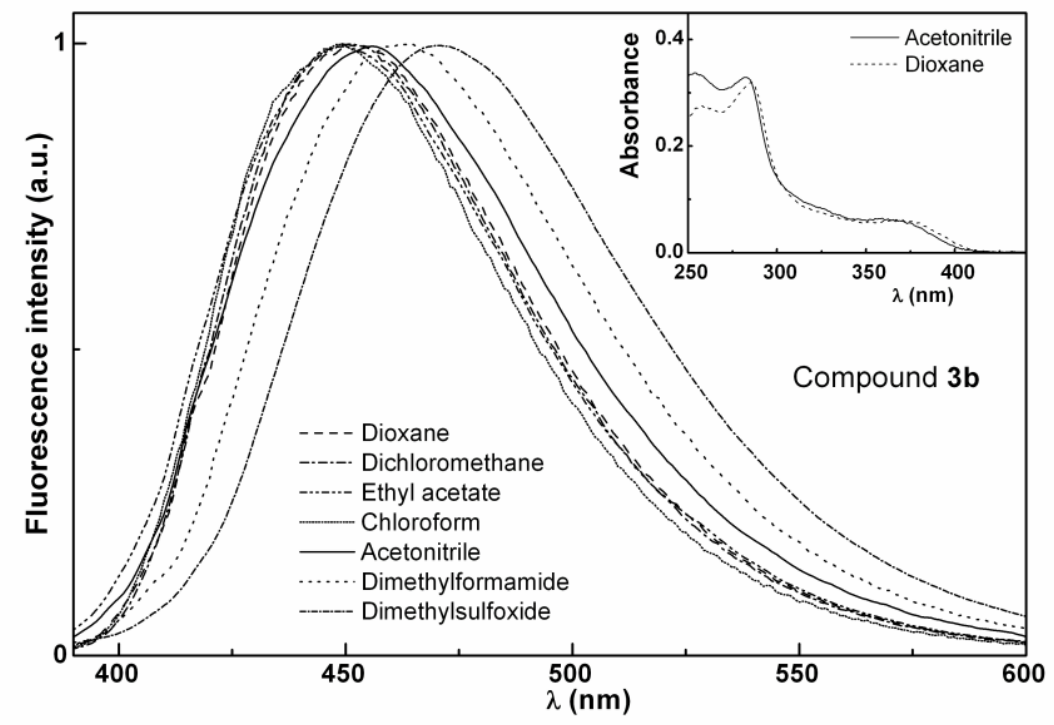

Figure 3. Normalized fluorescence spectra of $3 \times 10^{-6} \mathrm{M}$ solutions of compound $\mathbf{3 b}$ in several solvents $\left(\lambda_{\text {exc }}=370 \mathrm{~nm}\right)$. Inset: Absorption spectrum of $10^{-5} \mathbf{M}$ solutions of $\mathbf{3 b}$ in dioxane and acetonitrile, as examples.

This behavior, already observed for di(hetero)arylether derivatives of thieno[3,2-b]pyridines recently synthesized [21], can be due to specific solute-solvent interactions by hydrogen bonds with protic solvents, namely by protonation of the nitrogen atom of the pyridine ring. The same explanation can justify the low fluorescence quantum yields obtained in chloroform, as the formation of hydrogen bonds between chloroform and proton acceptor molecules has been already described [22].

The six compounds studied here are more fluorescent in polar solvents like dimethylformamide and dimethylsulfoxide, which is also a common behavior with the di(hetero)arylether derivatives of thieno[3,2-b]pyridines studied earlier [21]. Also, the substituent does not seem to have a significant influence in the fluorescence quantum yield values (Table SD1).

For all compounds, significant red shifts are observed for emission in polar solvents (34-36 $\mathrm{nm}$ between chloroform and dimethylsulfoxide for compounds 2a-c and 20-25 nm for 3a-c). In the absorption spectra, the red shifts are negligible (Table SD1), indicating that solvent relaxation after photoexcitation plays an important role, especially for compounds $\mathbf{2 a - c}$. This indicates that the 1,3-arylurea substituent in the meta position relative to $\mathrm{C}$ - $\mathrm{C}$ bond contributes to increase the intramolecular charge transfer (ICT) character of the excited state. 
The solvatochromic plots for compounds $\mathbf{2 a - c}$ and 3a-c, shown in Figures 4 and 5, are reasonably linear, the slope being larger for compound 2c. This predicts a higher ICT character of the excited state for this compound, maybe related with the position of the arylurea moiety together with the presence of a nitrile substituent.

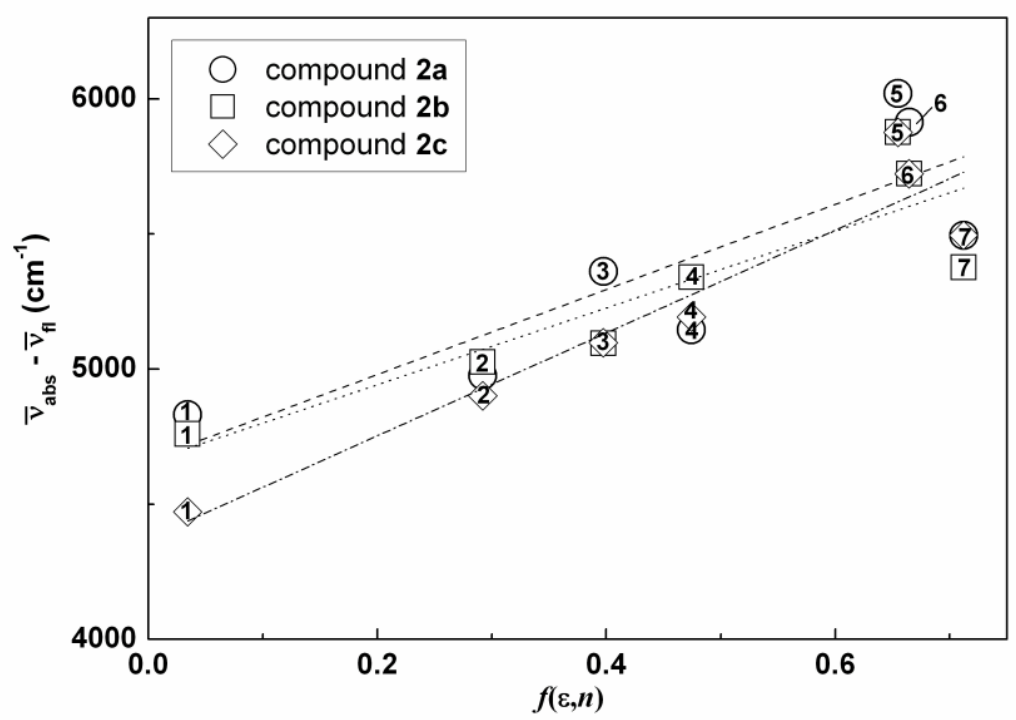

Figure 4. Solvatochromic plots (equation 4) for compounds 2a-c. Solvents: 1 - Dioxane; 2 chloroform; 3 - ethyl acetate; 4 - dichloromethane; 5 - dimethylsulfoxide; 6 - N,N-dimethylformamide; 7 - acetonitrile (values of $\varepsilon$ and $n$ were obtained from ref. [23]).

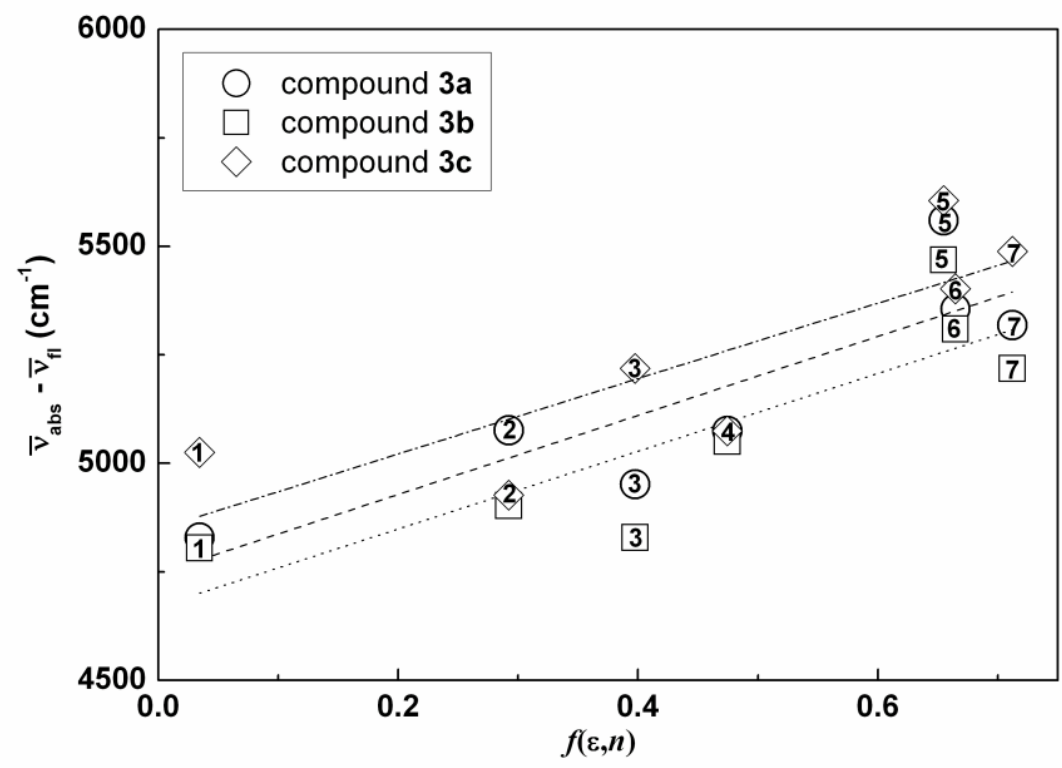

Figure 5. Solvatochromic plots (equation 4) for compounds 3a-c. Solvents: 1 - Dioxane; 2 chloroform; 3 - ethyl acetate; 4 - dichloromethane; 5 - dimethylsulfoxide; 6 - N,N-dimethylformamide; 7 - acetonitrile (values of $\varepsilon$ and $n$ were obtained from ref. [23]). 
The slopes of the solvatochromic plots are much lower for compounds 3a-c, being similar for these three molecules. This indicates that the charge transfer character of the excited state is much lower for the arylureas in the ortho position relative to the thieno[3,2- $b$ ]pyridine-2carboxylate moiety.

From $a b$ initio molecular quantum chemistry calculations, obtained with Gaussian 09 software [24] and use of a 6-311+G(dp) basis set at the DFT (CAM-B3LYP/AUTO) level of theory $[24,25]$ in gas phase, the cavity radius $(R)$ and the ground state dipole moment $\left(\mu_{\mathrm{g}}\right)$ were determined for the six compounds (Table 2). The use of CAM-B3LYP functional was needed, as initial trials with the simpler B3LYP gave unrealistic underestimates of the HOMO-LUMO band gap $(<500 \mathrm{~nm})$. This is a known problem with B3LYP functional in the description of excited states with charge transfer character [25]. The optimized geometries of the ground state and the first excited state were obtained with a smaller basis set $(3-21 \mathrm{G}+*)$ and are similar in the groups of compounds 2a-c and 3a-c (Figures 6 and 7). In the case of excited state calculations, a time dependent density functional method was used (TD-SCF DFT). In Table 1, the dihedral angle defined by the two molecular planes and the angles for the N-C-N and C-S-C chemical bonds (in the thienopyridine moiety) are indicated, evidencing notable differences in geometries between the two sets of compounds. Comparing the ground and excited state geometries, a small decrease ( $c a .10^{\circ}$ in $\mathbf{2 a - c}$ and $5^{\circ}$ in $\mathbf{3 a - c}$ ) of the dihedral angle is observed in the excited state (Table 1), together with a $2^{\circ}$ increase in the C-S-C bond angle for all compounds.

Table 1. Dihedral angle $\alpha, \mathrm{N}-\mathrm{C}-\mathrm{N}$ bond angle $\beta$ and C-S-C bond angle $\gamma$ in the ground and first singlet excited state geometries for compounds $\mathbf{2 a - c}$ and $\mathbf{3 a - c}$.

\begin{tabular}{|c|c|c|c|c|}
\hline Compound & State & Dihedral angle $\alpha$ & $\mathrm{N}-\mathrm{C}-\mathrm{N}$ angle $\beta$ & C-S-C angle $\gamma$ \\
\hline \multirow{2}{*}{$2 \mathbf{a}$} & Ground & $-46.6^{\circ}$ & $112.6^{\circ}$ & $90.1^{\circ}$ \\
\hline & Excited & $-36.8^{\circ}$ & $112.8^{\circ}$ & $92.6^{\circ}$ \\
\hline \multirow{2}{*}{$2 b$} & Ground & $-46.9^{\circ}$ & $112.5^{\circ}$ & $90.1^{\circ}$ \\
\hline & Excited & $-36.6^{\circ}$ & $112.8^{\circ}$ & $92.6^{\circ}$ \\
\hline \multirow{2}{*}{$2 c$} & Ground & $-47.0^{\circ}$ & $112.5^{\circ}$ & $90.1^{\circ}$ \\
\hline & Excited & $-36.1^{\circ}$ & $112.7^{\circ}$ & $92.6^{\circ}$ \\
\hline \multirow{2}{*}{$\mathbf{3 a}$} & Ground & $94.0^{\circ}$ & $112.3^{\circ}$ & $90.1^{\circ}$ \\
\hline & Excited & $89.6^{\circ}$ & $112.5^{\circ}$ & $92.7^{\circ}$ \\
\hline \multirow{2}{*}{$\mathbf{3 b}$} & Ground & $94.7^{\circ}$ & $112.2^{\circ}$ & $90.1^{\circ}$ \\
\hline & Excited & $89.0^{\circ}$ & $112.5^{\circ}$ & $92.8^{\circ}$ \\
\hline \multirow{2}{*}{$3 c$} & Ground & $94.0^{\circ}$ & $112.2^{\circ}$ & $90.1^{\circ}$ \\
\hline & Excited & $89.8^{\circ}$ & $112.4^{\circ}$ & $92.7^{\mathbf{o}}$ \\
\hline
\end{tabular}

The directions of the calculated dipole moments in the ground and excited states are also indicated in Figures 6 and 7, evidencing an increase in magnitude and a change of direction in 
the excited state dipole moment vector relative to the ground state one. This clearly indicates that the angle between the two dipole moment vectors cannot be neglected and must be considered in the solvatochromic plots (Bakhshiev's equation (4)). Nevertheless, the change in the dipole moment direction is very small for compounds $\mathbf{2 c}$ and $\mathbf{3 a}$. In the excited state, the dipole moment vectors for all compounds point to the side of the thienopyridine moiety.

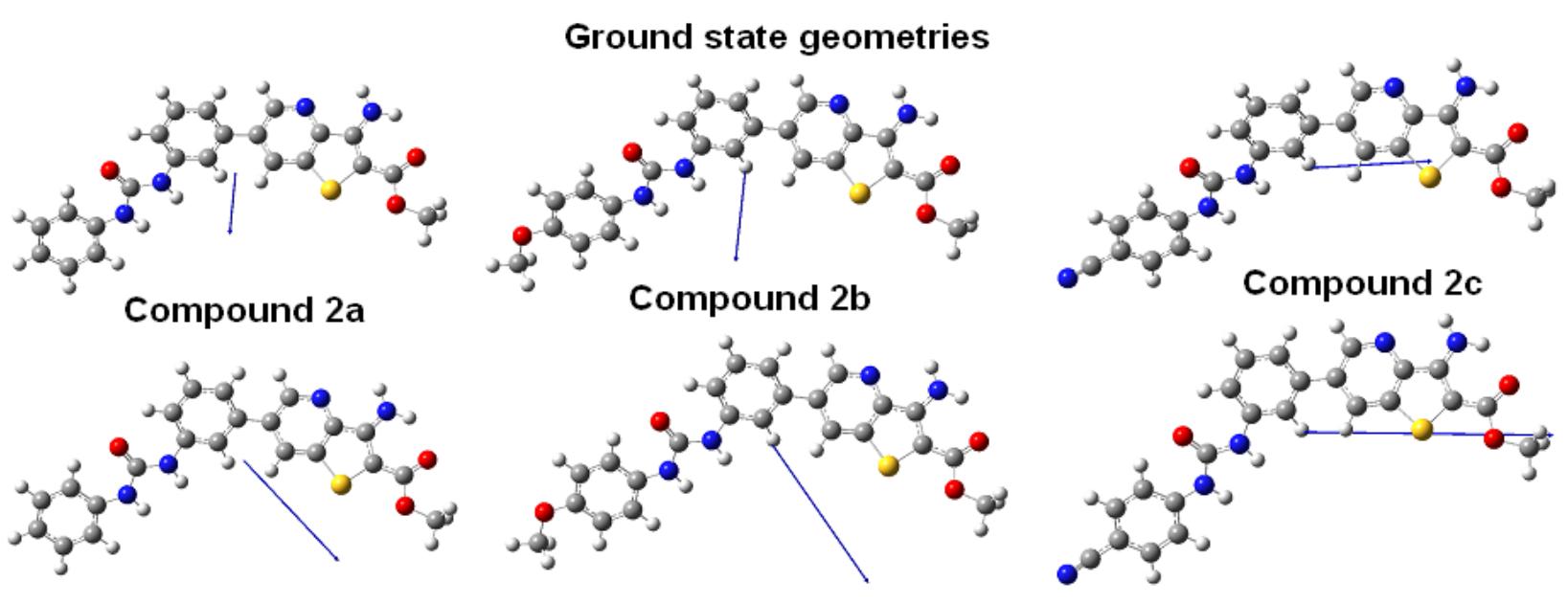

Excited state geometries

Figure 6. Optimized geometries of compounds 2a-c obtained by Gaussian 09 software (grey: C atoms; white: $\mathrm{H}$ atoms; red: $\mathrm{O}$ atoms; blue: $\mathrm{N}$ atoms; yellow: $\mathrm{S}$ atoms). Above: ground state; below: lowest excited singlet state. The arrows indicate the direction of the dipole moment.

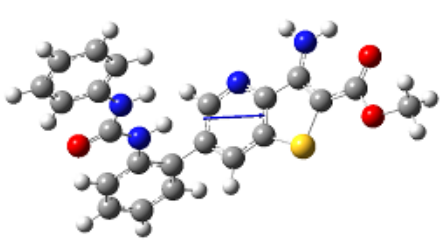

Compound $3 a$

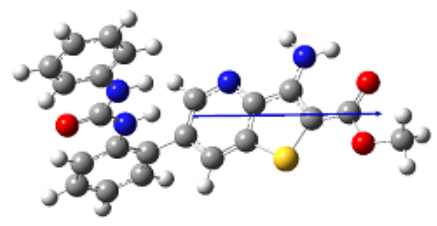

\section{Ground state geometries}

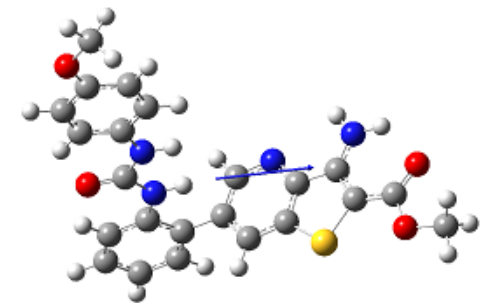

Compound $3 b$

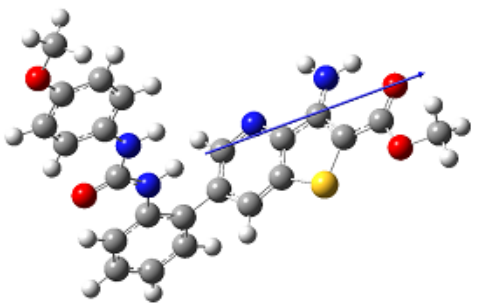

Excited state geometries

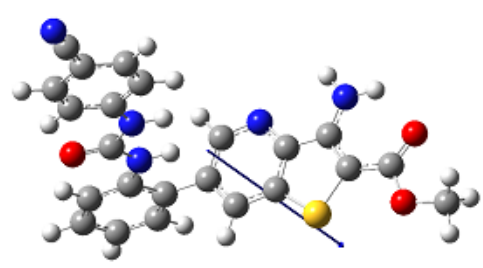

Compound 3c

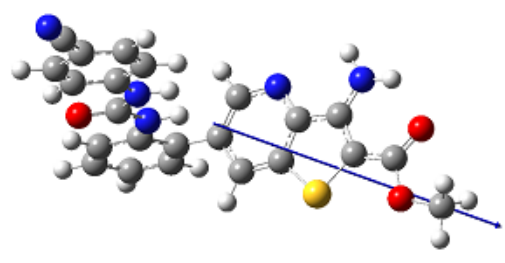

Figure 7. Optimized geometries of compounds 3a-c obtained by Gaussian 09 software (grey: C atoms; white: $\mathrm{H}$ atoms; red: $\mathrm{O}$ atoms; blue: $\mathrm{N}$ atoms; yellow: $\mathrm{S}$ atoms). Above: ground state; below: lowest excited singlet state. The arrows indicate the direction of the dipole moment. 
The absolute value of the difference in the excited and ground state dipole moment vectors, estimated from the solvatochromic plots (Figures 4 and 5) and from molecular quantum mechanical calculations, is presented in Table 2, for each compound. The obtained values are very similar and, therefore, both methods point to the presence of a charge transfer mechanism in the excited state, more pronounced for compounds $\mathbf{2 a - c}$. Compounds bearing an electron-donating group (- $\mathrm{OCH}_{3}$ in $\mathbf{2 b}$ ) or an electron-withdrawing group (-CN in $\mathbf{2 c}$ ) have a higher ICT character of the excited state than compound $\mathbf{2 a}$.

Table 2. Cavity radius $(R)$, ground $\left(\mu_{\mathrm{g}}\right)$ and excited state $\left(\mu_{\mathrm{e}}\right)$ dipole moments obtained from theoretical calculations, and absolute value of the dipole moment difference $\left(\left|\vec{\mu}_{\mathrm{e}}-\vec{\mu}_{\mathrm{g}}\right|\right)$, from quantum mechanical calculations and from the solvatochromic plots.

\begin{tabular}{cccccc}
\hline Compound & $\begin{array}{c}\text { Cavity } \\
\text { radius, } R \\
(\AA)\end{array}$ & $\begin{array}{c}\text { Ground state } \\
\text { dipole moment, } \\
\mu_{\mathrm{g}}(\mathrm{D})\end{array}$ & $\begin{array}{c}\text { Excited state dipole } \\
\text { moment, } \mu_{\mathrm{e}}(\mathrm{D}), \text { from } \\
\text { theoretical } \\
\text { calculations }\end{array}$ & $\begin{array}{c}\left|\vec{\mu}_{\mathrm{e}}-\vec{\mu}_{\mathrm{g}}\right|(\mathrm{D}) \\
\text { from theoretical } \\
\text { calculations }\end{array}$ & $\begin{array}{c}\left|\vec{\mu}_{\mathrm{e}}-\vec{\mu}_{\mathrm{g}}\right| \text { (D) from } \\
\text { solvatochromic } \\
\text { plots }\end{array}$ \\
\hline 2a & 5.6 & 3.1 & 6.1 & 5.1 & 5.2 \\
$\mathbf{2 b}$ & 6.2 & 4.7 & 7.3 & 5.2 & 5.8 \\
2c & 5.9 & 4.9 & 10.1 & 5.3 & 6.2 \\
3a & 5.7 & 2.2 & 6.7 & 4.6 & 4.1 \\
3b & 6.0 & 3.3 & 7.8 & 4.5 & 4.4 \\
3c & 5.9 & 7.4 & 10.2 & 4.7 & 4.2 \\
\hline
\end{tabular}

Figure 8 displays the representation of electronic density difference between the lowest excited state and the ground state, for the lowest excited state optimized geometry (relaxed $S_{1}$ state). In general, it can be observed that electron density variations reside mostly on the thienopyridine-2-carboxylate moiety. This justifies that the compounds do not exhibit a noticeable influence of the arylurea substituent $\left(-\mathrm{OCH}_{3}\right.$ or $\left.-\mathrm{CN}\right)$ in their photophysical properties, namely in the fluorescence quantum yields. The more prominent features in Figure 8 are an electron density transfer from the amino group linked to the thiophene ring and its sulfur atom to the nitrogen atom in the pyridine moiety and to the carboxylate group. In the $\pi$ electron system, alternating increases and decreases of electronic density are observed. This confirms the ICT character of the first excited state of these compounds. 


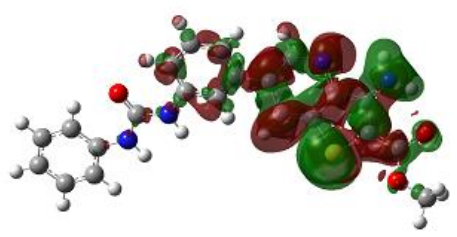

Compound 2a

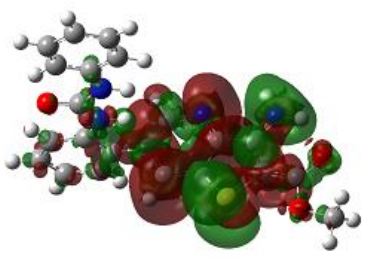

Compound 3a

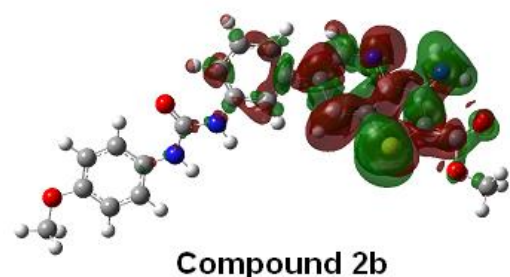

Compound $2 b$

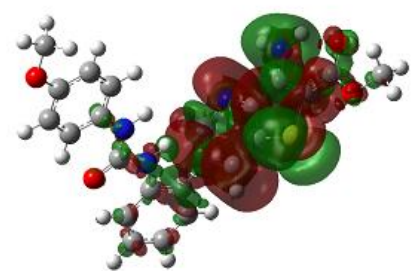

Compound $3 b$
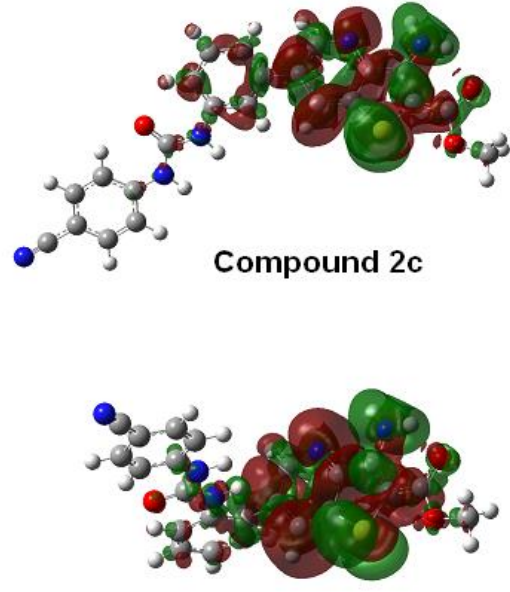

Compound 3c

Figure 8. Representation of the electronic density difference for compounds $\mathbf{2 a - c}$ and 3a-c (optimized geometry for the lowest excited singlet state) at an iso level of 0.0004; green regions: loss of electronic density; red regions: enrichment of electronic density.

The photophysical behavior of the six compounds shows that they can be considered as solvatochromic probes, especially compounds 2a-c. The sensitivity of the fluorescence emission to the fluorophore environment can be very useful when probing the location/behavior of these compounds in lipid membranes.

\subsection{Fluorescence studies in lipid membranes}

Fluorescence experiments of the six compounds incorporated in lipid membranes of several compositions were carried out. These lipid aggregates were composed either by neat phospholipids, or by phosphatidylcholines with cholesterol $(\mathrm{Ch})$, for a better simulation of the biological membranes. In fact, the vesicles composed of $70 \%$ Egg-PC and 30\% cholesterol (Egg-PC:Ch 7:3) are often used as models of the biological membranes [26,27].

Lipid membranes of neat DPPC (zwitterionic), DPPG (anionic), DODAB (cationic), Egg-PC (zwitterionic, composed of a phosphatidylcholine mixture), Egg-PC:Ch 7:3 and DPPC:Ch $7: 3$, with incorporated compounds, were prepared and the fluorescence emission was monitored in both gel (below the main transition temperature, $T_{\mathrm{m}}$ ) and liquid-crystalline (above $T_{\mathrm{m}}$ ) phases of the phospholipids. At room temperature, the phospholipids DPPC, DODAB and DPPG are in ordered gel phase, where the hydrocarbon chains are fully extended and closely packed. The melting transition temperature of Egg-PC is very low [28] and this lipid is in the fluid liquid-crystalline phase at room temperature. 
Fluorescence spectra of compounds incorporated in these lipid aggregates are presented in Figures 9 and 10. All the six compounds exhibit reasonable fluorescence emission when incorporated in lipid membranes, indicating that they are mainly located in the region of the lipid bilayer, as they are not fluorescent in alcohols or water. The maximum emission wavelengths in lipid membranes generally point to a hydrophobic medium for all compounds in these lipid aggregates, feeling an environment with polarity near dioxane or less polar than dioxane (Table 3). A slightly more hydrated environment is anticipated for the six compounds in DPPG vesicles at $25^{\circ} \mathrm{C}$, considering the values of the maximum emission wavelengths.

Fluorescence anisotropy $(r)$ measurements can give relevant information about the location of the compounds in liposomes, as $r$ increases with the rotational correlation time of the fluorescent molecule (and, thus, with the viscosity of the fluorophore environment) [29].

Steady-state anisotropy relates to both the excited-state lifetime and the rotational correlation time of the fluorophore [29],

$$
\frac{1}{r}=\frac{1}{r_{0}}\left(1+\frac{\tau}{\tau_{\mathrm{c}}}\right)
$$

where $r_{0}$ is the fundamental anisotropy, $\tau$ is the excited-state lifetime and $\tau_{\mathrm{c}}$ is the rotational correlation time.

The fluorescence steady-state anisotropies of compounds 2a-c and 3a-c in lipid membranes are shown in Table 3. Anisotropy values in glycerol at room temperature were also determined for comparison.

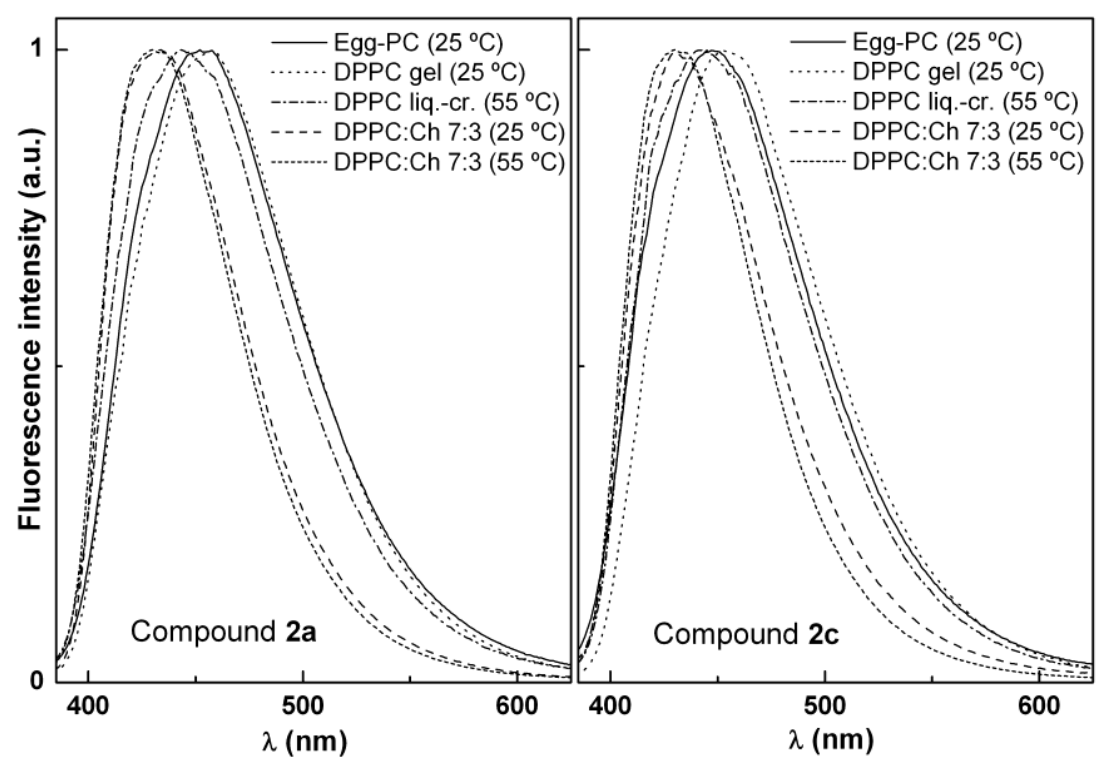

Figure 9. Normalized fluorescence spectra of compounds $2 \mathbf{a}$ and $2 \mathbf{c}\left(3 \times 10^{-6} \mathrm{M}\right)$ in lipid aggregates of Egg-PC, Egg-PC:Ch, DPPC and DPPC:Ch, at $25^{\circ} \mathrm{C}$ and $55^{\circ} \mathrm{C}$. 


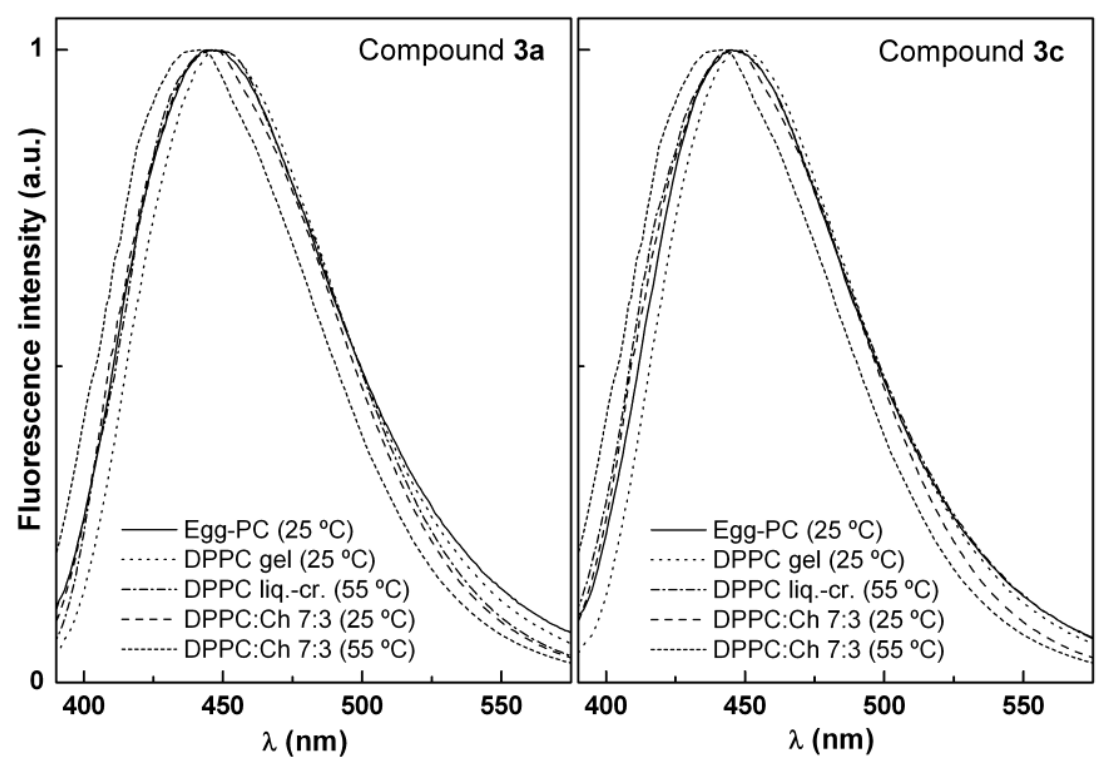

Figure 10. Normalized fluorescence spectra of compounds $3 \mathbf{a}$ and $3 \mathbf{c}\left(3 \times 10^{-6} \mathrm{M}\right)$ in lipid aggregates of Egg-PC, Egg-PC:Ch, DPPC and DPPC:Ch, at $25^{\circ} \mathrm{C}$ and $55^{\circ} \mathrm{C}$.

Table 3. Steady-state fluorescence anisotropy $(r)$ values and maximum emission wavelengths $\left(\lambda_{\text {em }}\right)$ for compounds 2a-c and 3a-c in lipid aggregates, below $\left(25^{\circ} \mathrm{C}\right)$ and above $\left(55^{\circ} \mathrm{C}\right)$ transition temperature of the lipids. Anisotropy values in glycerol at room temperature are also shown for comparison.

\begin{tabular}{|c|c|c|c|c|c|c|c|c|c|c|c|c|c|}
\hline \multirow[b]{2}{*}{ Lipid } & \multirow{2}{*}{$\begin{array}{c}\mathrm{T} \\
\left({ }^{\circ} \mathrm{C}\right)\end{array}$} & \multicolumn{2}{|c|}{$2 a$} & \multicolumn{2}{|c|}{$2 b$} & \multicolumn{2}{|c|}{$2 c$} & \multicolumn{2}{|c|}{$3 a$} & \multicolumn{2}{|c|}{$3 \mathbf{b}$} & \multicolumn{2}{|c|}{$3 c$} \\
\hline & & $\begin{array}{r}\lambda_{\mathrm{em}} \\
(\mathrm{nm})\end{array}$ & $r$ & $\begin{array}{c}\lambda_{\mathrm{em}} \\
(\mathrm{nm})\end{array}$ & $r$ & $\begin{array}{c}\lambda_{\mathrm{em}} \\
(\mathrm{nm})\end{array}$ & $r$ & $\begin{array}{c}\lambda_{\mathrm{em}} \\
(\mathrm{nm})\end{array}$ & $r$ & $\begin{array}{c}\lambda_{\mathrm{em}} \\
(\mathrm{nm})\end{array}$ & $r$ & $\begin{array}{c}\lambda_{\mathrm{em}} \\
(\mathrm{nm})\end{array}$ & $r$ \\
\hline Egg-PC & 25 & 452 & 0.221 & 449 & 0.205 & 451 & 0.210 & 449 & 0.248 & 451 & 0.249 & 449 & 0.240 \\
\hline $\begin{array}{c}\text { Egg-PC:Ch } \\
(7: 3)\end{array}$ & 25 & 443 & 0.197 & 440 & 0.187 & 443 & 0.190 & 446 & 0.228 & 446 & 0.221 & 445 & 0.231 \\
\hline \multirow{2}{*}{ DPPC } & 25 & 458 & 0.238 & 459 & 0.232 & 452 & 0.262 & 452 & 0.256 & 451 & 0.259 & 452 & 0.251 \\
\hline & 55 & 443 & 0.168 & 441 & 0.167 & 443 & 0.175 & 449 & 0.163 & 448 & 0.122 & 449 & 0.180 \\
\hline \multirow{2}{*}{$\begin{array}{c}\text { DPPC:Ch } \\
\quad(7: 3)\end{array}$} & 25 & 434 & 0.172 & 438 & 0.175 & 439 & 0.192 & 450 & 0.199 & 449 & 0.171 & 450 & 0.194 \\
\hline & 55 & 430 & 0.143 & 432 & 0.136 & 431 & 0.155 & 446 & 0.104 & 445 & 0.118 & 446 & 0.127 \\
\hline \multirow{2}{*}{ DODAB } & 25 & 457 & 0.229 & 457 & 0.200 & 453 & 0.243 & 448 & 0.230 & 456 & 0.251 & 451 & 0.247 \\
\hline & 55 & 446 & 0.182 & 447 & 0.167 & 446 & 0.131 & 445 & 0.172 & 444 & 0.180 & 444 & 0.183 \\
\hline \multirow{2}{*}{ DPPG } & 25 & 467 & 0.230 & 466 & 0.223 & 466 & 0.250 & 461 & 0.233 & 464 & 0.226 & 457 & 0.209 \\
\hline & 55 & 457 & 0.181 & 458 & 0.190 & 457 & 0.195 & 457 & 0.149 & 460 & 0.138 & 454 & 0.102 \\
\hline Glycerol & 25 & 474 & 0.325 & 465 & 0.295 & 469 & 0.308 & 464 & 0.330 & 462 & 0.327 & 459 & 0.324 \\
\hline
\end{tabular}

Steady-state fluorescence anisotropy results (Table 3) allow concluding that all compounds are mainly located in the inner region of the lipid membrane. The transition from the rigid gel phase to the fluid liquid-crystalline phase is clearly detected by a notable decrease in anisotropy at $55^{\circ} \mathrm{C}$. An increase of the steady-state anisotropy is predicted from a decrease of the excited-state lifetime (equation 7). Upon rising temperature (from $25{ }^{\circ} \mathrm{C}$ to $55^{\circ} \mathrm{C}$ ), the excited-state lifetime decreases due to the increase of non-radiative deactivation pathways 
(mainly the rate constant for internal conversion $S_{1} \rightarrow S_{0}$ ). Instead of an expected rise in anisotropy (equation 7), a decrease is observed, which can only be attributed to a diminution of the rotational correlation time of the fluorophore, that arises from the decrease of membrane microviscosity upon changing from the gel to the liquid-crystalline phase.

Fluorescence anisotropy values for the compounds incorporated in lipid membranes exhibit also a significant decrease when lipid aggregate fluidity increases by addition of cholesterol. Simultaneously, a blue shift in emission spectra (Figures 9 and 10 and Table 3) is observed when fluidity increases, either by phase transition to the liquid-crystalline phase or by cholesterol addition. These changes are much more pronounced for compounds $\mathbf{2 a - c}$ and may indicate a relocation of the fluorophores in a less hydrated environment. The decrease in local microviscosity can facilitate a deeper penetration of these molecules in lipid bilayers. The results obtained here point to a promising utility of the new diarylureas to monitor changes in fluidity of lipid membranes, especially compounds $\mathbf{2 a - c .}$

Microviscosity in hydrophobic domains of microheterogeneous systems has been measured using the widely known fluorescence probe 1,3-bis-(1-pyrenyl)propane (BPP) [30-35]. This probe can form intramolecular excimers and is highly sensitive to constraints imposed by its environment, reported by variations in the ratio between excimer and monomer emission intensities. The new diarylurea derivatives $\mathbf{2 a - c}$ and 3a-c showed in this work an interesting potential as fluidity probes for lipid membranes (especially 2a-c) through their intrinsic photophysical properties, rather than by the relative efficiency of a dynamic conformational change leading to an intramolecular pyrene excimer formation, as observed in BPP. However, further studies are needed to assess the utility of these new probes for microviscosity determinations of other types of microheterogeneous systems already studied using BPP, like micelles, liquid crystals, lipoproteins and synthetic polymers [30, 33-35].

\section{Conclusions}

New six fluorescent 1,3-diarylureas in the thieno[3,2-b]pyridine series were prepared by a reaction of ortho and meta aminated Suzuki coupling products obtained by the formation of a $\mathrm{C}-\mathrm{C}$ bond in the 6-position of the thieno[3,2- $b]$ pyridine moiety, with different parasubstituted arylisocyanates ( $\mathrm{H}, \mathrm{OMe}$ or $\mathrm{CN})$.

The six compounds exhibit reasonable fluorescence quantum yields in several solvents and present a moderately solvent sensitive emission, but are not fluorescent in alcohols and water. 
Compounds $\mathbf{2 b}$ and $\mathbf{2 c}$ with the arylurea moiety in the meta position and bearing a OMe or $\mathrm{CN}$ group, are the ones with better solvatochromic properties.

Incorporation of compounds $\mathbf{2 a - c}$ and 3a-c in lipid membranes indicate that all compounds are deeply located in the hydrophobic region of the lipid bilayers, feeling the transition between the rigid gel phase and the liquid-crystalline phase. The results obtained point to a promising utility of these compounds to monitor changes in fluidity of lipid membranes, especially compounds 2a-c. Moreover, due to the potential biological activity of these new compounds, their interaction with lipid membranes is of particular interest.

\section{Supplementary Data}

Table SD1. Maximum absorption ( $\left.\lambda_{\text {abs }}\right)$ and emission wavelengths $\left(\lambda_{\text {em }}\right)$, molar absorption coefficients $(\varepsilon)$ and fluorescence quantum yields $\left(\Phi_{\mathrm{F}}\right)$ for compounds $\mathbf{2 a - c}$ and 3a-c in several solvents.

\section{Acknowledgements}

To the Foundation for the Science and Technology (FCT, Portugal) for inancial support to the NMR portuguese network (PTNMR, Bruker Avance III 400-Univ. Minho). To the FCT and FEDER (European Fund for Regional Development)-COMPETE-QREN-EU for financial support to the Research Centres, CQ/UM [PEst-C/QUI/UI0686/2011 (FCOMP-01-0124FEDER-022716)] and CFUM [PEst-C/FIS/UI0607/2011 (F-COMP-01-0124-FEDER022711)], and to the research projects PTDC/QUI/81238/2006 (FCOMP-01-0124-FEDER007467) (photophysical studies) and PTDC/QUI-QUI/111060/2009 (F-COMP-01-0124FEDER-015603) (organic synthesis).

\section{References}

[1] V. Amendola, L. Fabbrizzi, L. Mosca, Anion recognition by hydrogen bonding: urea-based receptors, Chem. Soc. Rev. 39 (2010) 3889-3915.

[2] K. Lang, J. Park, S. Hong, Urea/transition-metal cooperative catalyst for anti-selective asymmetric nitroaldol reactions, Angew. Chem. Int. Ed. 51(7) (2012) 1620-1624.

[3] J. G. Kim, Y. Takami, T. Mizugami, K. Beppu, T. Fukuda, I. Kataoka, CPPU application on size and quality of hardy kiwifruit, Sci. Hortic. 110 (2006) 219-222.

[4] I. Hayakama, R. Shioya, T. Agatsuma, H. Furokawa, Y. Sugano, Thienopyridine and benzofuran derivatives as potent anti-tumor agents possessing different structure-activity relationship, Bioorg. Med. Chem. 14 (2004) 3411-3414. 
[5] H. R. Heyman, R. R. Frey, P. F. Bousquet, G. A. Cunha, M. D. Moskey, A. A. Ahmed, N. B. Soni, P. A. Marcotte, L. J. Pease, K. B.Glaser, M. Yates, J. J. Bouska, D. H. Albert, C. L. Black Schaefer, P. J. Dandliker, K. D.Stewart, P. Rafferty, S. K. Davidsen, M. R. Michaelides, M. L. Curtin, Thienopyridine urea inhibitors of KDR kinase, Bioorg. Med. Chem. Lett. 17 (2007) 1246-1249.

[6] M.-J. R. P. Queiroz, R. C. Calhelha, L. A. Vale-Silva, E. Pinto, R. T. Lima, M. H. Vasconcelos, Efficient synthesis of 6-(hetero)arylthieno[3,2-b]pyridines by Suzuki-Miyaura coupling. Evaluation of growth inhibition in human tumor cell lines, SARs and effects on the cell cycle, Eur. J. Med. Chem. 45 (2010) 5628-5634.

[7] Y. Malam, M. Loizidou, A. M. Seifalian, Liposomes and nanoparticles: nanosized vehicles for drug delivery in cancer, Trends in Pharmacol. Sci. 30 (2009) 592-599.

[8] S. Batzri, E. D. Korn, Single bilayer liposomes prepared without sonication, BBA: Biomembranes 298 (1973) 1015-1019.

[9] J. M. H. Kremer, M. W. J. v. d. Esker, C. Pathmamanoharan, P. H. Wiersema, Vesicles of variable diameter prepared by a modified injection method, Biochemistry 16 (1977) 3932-3935.

[10] J. R. Nordlund, C. F. Schmidt, S. N. Dicken, T. E. Thompson, Transbilayer distribution of phosphatidylethanolamine in large and small unilamellar vesicles, Biochemistry 20 (1981) 3237-3241.

[11] B. R. Lentz, Membrane "fluidity" as detected by diphenylhexatriene probes, Chem. Phys. Lipids 50 (1989) 171-190.

[12] E. Feitosa, P. C. A. Barreleiro, G. Olofsson, Phase transition in dioctadecyldimethylammonium bromide and chloride vesicles prepared by different methods, Chem. Phys. Lipids 105 (2000) 201-213.

[13] J. S. Vincent, S. D. Revak, C. D. Cochrane, I. W. Levin, Interactions of model human pulmonary surfactants with a mixed phospholipid bilayer assembly: Raman spectroscopic studies, Biochemistry 32 (1993) 8228-8238.

[14] J. N. Demas, G. A. Crosby, Measurement of photoluminescence quantum yields - Review, J. Phys. Chem. 75 (1971) 991-1024.

[15] S. Fery-Forgues, D. Lavabre, Are fluorescence quantum yields so tricky to measure? A demonstration using familiar stationery products, J. Chem. Educ. 76 (1999) 1260-1264.

[16] S. R. Meech, D. Phillips, Photophysics of some common fluorescence standards, J. Photochem. 23 (1983) 193-217.

[17] J. R. Lakowicz, Principles of Fluorescence Spectroscopy, Kluwer Academic/Plenum Press, New York, 1999.

[18] N. Mataga, T. Kubota, Molecular Interactions and Electronic Spectra, Marcel Dekker, New York, 1970.

[19] N. G. Bakhshiev, Universal molecular interactions and their effects on the position of the electronic spectra of molecules in two component solutions. I. Theory (liquid solutions), Opt. Spectrosc. 10 (1961) 379-384.

[20] N. G. Bakhshiev, Universal molecular interactions and their effects on the position of the electronic spectra of molecules in two component solutions, Opt. Spectrosc. 12 (1962) 309-313; Opt. Spectrosc. 13 (1962) 24-29.

[21] M.-J. R. P. Queiroz, S. Dias, D. Peixoto, A. R. O. Rodrigues, A. D. S. Oliveira, P. J. G. Coutinho, L. A. Vale-Silva, E. Pinto, E. M. S. Castanheira, New potential antitumoral di(hetero)arylether derivatives in the thieno[3,2- $b]$ pyridine series: Synthesis and fluorescence studies in solution and in nanoliposomes, J. Photochem. Photobiol. A: Chemistry 238 (2012) 71-80. 
[22] (a) K. C. James, P. R. Noyce, Hydrogen bonding between testosterone propionate and solvent in chloroform-cyclohexane solutions, Spectrochim. Acta A 27 (1971) 691-696. (b) G. R. Wiley, S. I. Miller, Thermodynamic parameters for hydrogen-bonding of chloroform with Lewis bases in cyclohexane - Proton magnetic-resonance study, J. Am. Chem. Soc. 94 (1972) 3287-3293.

[23] D. R. Lide (Ed.), Handbook of Chemistry and Physics, 83th Edition, CRC Press, Boca Raton, 2002.

[24] Gaussian 09, Revision A.02, M. J. Frisch, G. W. Trucks, H. B. Schlegel, G. E. Scuseria, M. A. Robb, J. R. Cheeseman, G. Scalmani, V. Barone, B. Mennucci, G. A. Petersson, H. Nakatsuji, M. Caricato, X. Li, H. P. Hratchian, A. F. Izmaylov, J. Bloino, G. Zheng, J. L. Sonnenberg, M. Hada, M. Ehara, K. Toyota, R. Fukuda, J. Hasegawa, M. Ishida, T. Nakajima, Y. Honda, O. Kitao, H. Nakai, T. Vreven, J. A. Montgomery, Jr., J. E. Peralta, F. Ogliaro, M. Bearpark, J. J. Heyd, E. Brothers, K. N. Kudin, V. N. Staroverov, R. Kobayashi, J. Normand, K. Raghavachari, A. Rendell, J. C. Burant, S. S. Iyengar, J. Tomasi, M. Cossi, N. Rega, J. M. Millam, M. Klene, J. E. Knox, J. B. Cross, V. Bakken, C. Adamo, J. Jaramillo, R. Gomperts, R. E. Stratmann, O. Yazyev, A. J. Austin, R. Cammi, C. Pomelli, J. W. Ochterski, R. L. Martin, K. Morokuma, V. G. Zakrzewski, G. A. Voth, P. Salvador, J. J. Dannenberg, S. Dapprich, A. D. Daniels, Ö. Farkas, J. B. Foresman, J. V. Ortiz, J. Cioslowski, and D. J. Fox, Gaussian, Inc., Wallingford CT, 2009.

[25] (a) T. Yanaia, D. P. Tewb, N. C. Handy, A new hybrid exchange-correlation functional using the Coulomb-attenuating method (CAM-B3LYP), Chem. Phys. Lett. 393 (2004) 51-57. (b) M. J. G. Peach, T. Helgaker, P. Sałek, T. W. Keal, O. B. Lutnæs, D. J. Tozer, N. C. Handy, Assessment of a Coulomb-attenuated exchange-correlation energy functional, Phys. Chem. Chem. Phys. 8 (2006) 558-562.

[26] C. Toniolo, M. Crisma, F. Formaggio, C. Peggion, V. Monaco, C. Goulard, S. Rebuffat, B. Bodo, Effect of $N^{\alpha}$-acyl chain length on the membrane-modifying properties of synthetic analogs of the lipopeptaibol trichogin GA IV, J. Am. Chem. Soc. 118 (1996) 4952-4958.

[27] M. Crisma, A. Barazza, F. Formaggio, B. Kaptein, B. Q. Broxterman, J. Kamphuis, C. Toniolo, Peptaibolin: synthesis, 3D-structure, and membrane modifying properties of the natural antibiotic and selected analogues, Tetrahedron 57 (2001) 2813-2825.

[28] D. Papahadjopoulos, N. Miller, Phospholipid model membranes. I. Structural characteristics of hydrated liquid crystals, Biochim. Biophys. Acta 135 (1967) 624-638.

[29] B. Valeur, Molecular Fluorescence - Principles and Applications, Weinheim, Wiley-VCH, 2002.

[30] R. L. Melnick, H. C. Haspel, M. Goldenberg, L. M. Greenbaum, S. Weinstein, Use of fluorescent probes that form intramolecular excimers to monitor structural changes in model and biological membranes, Biophys. J. 34 (1981) 499-515.

[31] L. M. Almeida, W. L. Vaz, K. A. Zachariasse, V. M. Madeira, Fluidity of sarcoplasmic reticulum membranes investigated with dipyrenylpropane, an intramolecular excimer probe, Biochemistry 21 (1982) 5972-5977.

[32] S. Kang, I. G. Kang, I. Yun, Determination of microviscosity and location of 1,3-di(1pyrenyl)propane in brain membranes, Arch. Pharm. Res. 20 (1997) 1-6.

[33] E. Szajdzinska-Pietek, M. Wolszczak, A. Plonka, S. Schlick, Fluorescence studies of selfassembling in aqueous solutions of poly(ethylene-co-methacrylic acid) (EMAA) ionomers, J. Am. Chem. Soc. 120 (1998) 4215-4221.

[34] Y. Díaz-Fernández, S. Rodríguez-Calvo, A. Pérez-Gramatges, P. Pallavicini, S. Patroni, C. Mangano, Effect of surfactant structure on the residual fluorescence of micelle-based fluorescent probes, J. Colloid Interface Sci. 313 (2007) 638-644. 
[35] Y. A. Díaz-Fernández, E. Mottini, L. Pasotti, E. F. Craparo, G. Giammona, G. Cavallaro, P. Pallavicini, Multicomponent polymeric micelles based on polyaspartamide as tunable fluorescent pH-window biosensors, Biosens. Bioelectron. 26 (2010) 29-35. 